No. 29, September 1965

\title{
ニ三の安定同位体の地球化学について（IV） 海水の安定同位体地球化学
}

\author{
On the Geochemical Studies of Stable Isotopes (IV) \\ On the Isotope Geochemistry of Sea Water \\ 島 \\ 誠* \\ Makoto Shima
}

(1965年 6 月 25 日受理)

\begin{abstract}
Since the pioneering work of the chemical compositions of the sea water, numerous quantitative analyses have been carried out for supplying the chemical composition table of the sea water. However, a few studies on the isotopic compositions of these elements in the ocean have been reported in the present time. Although the isotopic study of ocean has many difficulties, we can measure with high accuracy and probably represent very accurately the basic ratio for the chemical elements isotope ratio, at least for some elements. According to literatures, the stable isotopic compositions of $\mathrm{D}, \mathrm{Li}, \mathrm{B}, \mathrm{C}, \mathrm{N}, \mathrm{O}, \mathrm{Mg}, \mathrm{S}, \mathrm{Cl}, \mathrm{K}, \mathrm{Ca}, \mathrm{Fe}, \mathrm{Br}, \mathrm{Sr}, \mathrm{Pb}$ and also some natural radio isotope elements in the sea water are collected in this paper. This work is presented as an attempt to provide informations about the isotope geochemistry on the sea water.
\end{abstract}

\section{1.まえがき}

地球化学の研究における海水の位置は, 直接に生物 圈に接して地球の表而の約71\%を占め，加地表にお ける温度において気体，液体およで固体の 3 相を保ち， 地表のあらゆる部分を循環するてとができる上色々 な物質を溶解し，運搬し，沈稓させる能力を有する重 要なものである。地表には海水以外飞も, 河川水, 湖 水，地下水など種々の水も存在するが，水圈全体とし てはその約 $98 \%$ 占める海水が地表の水圈を代表し得 ると考元られる。

海水の化学成分の表としては, 通常 Table 1 亿引 用するものが代表的なものである”。乙の表では，各 元素の溶在状態之か生物活動に関連する若干の量の変 動および地域性に伴う変化などはあまり考察されてい ない。しかし，海水を化学的に研究するための根処と しては重要な尺度となる。

海水は相当に湠い無機電解質の溶液であり, 水とそ の中にとけている嫶類の成因と経過を考察し, 現在の 組成になるまでの地球化学的研究は, 元素または塭類 を中心に行われてきた。近年, 元素または塩類以外に 安定同位体を用いて，海水の成因や地球化学的輪回お

*理化学研究所,地球化学研究室(東京都文京区上富士前町) The Inst. of Physical and Chemical Research, Geochemical laboratory (Kamifujimae, Bunkyo, Tokyo,)
よび物理化学的な性質が追求されている。海水中に存 在しかつ測定し易い元素，例えば $\mathrm{D}, \mathrm{C}, \mathrm{O}$, および $\mathrm{S}$ などについては，それらの同位体比の測定による多く の報告がある。しかし，海水中に存在する他の多くの 元素については，同位体比測定の困難さおよご地球化 学的な興味が比較的に少いという理由などによって, 未だ報告が少い。しかしながら, 地球化学の研究にお いては，従来元素の量を一つの尺度として発展してき た様に，同位体を尺度として考察する場合においてす 海水の化学成分表 Table 1 亿相当するような海水の 安定同位体比表の必要があると思われる。

そこで，現在までに集められた個々の元素の報告を 採り上げて表を試作した。

むちろん，同位体比の測定においては，未だ発展途 上にある研究であるから，標準または参考試料などで 若干の混乱などがあり21，必ずしも研究報告個々の值 を直接に比較㭘討できないすのも多い。しかし，同位 体比を利用するととにより従来の元素だけでは追跡し 得ないような現象をより確実に解明できる可能性があ り，同位体比を利用する研究は今後益々盛になると考 えられる。この表がそれらの研究に一つの段階になる と考元, 取緾めた。

\section{2. 海水中の安定同位体}

Table 1 には，安定同位体のある元素に○印を， 
Table 1. Chemical Composition of sea water.

\begin{tabular}{|c|c|c|c|c|c|}
\hline & {$[\mathrm{mg} / l]$} & {$\left[\right.$ atom $/ 10^{6}$ atom $\left.\mathrm{Cl}\right]$} & & {$[\mathrm{mg} / l]$} & {$\left[\right.$ atom $/ 10^{6}$ atom $\left.\mathrm{Cl}\right]$} \\
\hline$\odot \mathrm{H}^{*}$ & 108,000 & $202,000,000$ & $\bigcirc \mathrm{Ag}$ & 0.003 & 0.005 \\
\hline$\bigcirc \mathrm{He}$ & 0.00001 & 0.0004 & $\bigcirc \mathrm{Cd}$ & 0.000055 & 0.0009 \\
\hline$\odot \mathrm{Li}$ & 0.2 & 50. & $\bigcirc \operatorname{In} *$ & $<0.02$ & $<0.3$ \\
\hline $\mathrm{Be}-$ & & & $\bigcirc \mathrm{Sn}$ & 0.003 & 0.05 \\
\hline$\odot \mathrm{B}$ & 4.8 & 830. & OSb* & $<0.0005$ & $<0.008$ \\
\hline$\odot \mathrm{C}^{*}$ & 28. & 4,300 . & $\bigcirc \mathrm{Te}$ & & \\
\hline$\odot \mathrm{N}$ & 0.5 & 70. & $\mathrm{I}-$ & 0.4 & 0.6 \\
\hline$\odot \mathrm{O}$ & 857,000 . & $100,000,000$ & $\bigcirc \mathrm{Xe}$ & 0.0001 & 0.001 \\
\hline $\mathrm{F}-$ & 1.3 & 130. & $\mathrm{Cs}-$ & 0.001 & 0.01 \\
\hline$\bigcirc \mathrm{Ne}$ & 0.0003 & 0.03 & $\mathrm{OBa}$ & $<0.09$ & $<1.2$ \\
\hline $\mathrm{Na}-$ & 10,500 & 850,000 . & $\bigcirc \mathrm{La}^{*}$ & 0.0003 & 0.004 \\
\hline$\odot \mathrm{Mg}$ & 1,300 . & 100,000 . & $\bigcirc \mathrm{Ce}^{*}$ & 0.0004 & 0.005 \\
\hline $\mathrm{Al}-$ & 0.01 & 0.7 & $\mathrm{Pr}-$ & & \\
\hline OSi & 3. & 200. & $\bigcirc \mathrm{Nd}^{*}$ & & \\
\hline $\mathrm{P}-$ & 0.07 & 4. & $\mathrm{Pm}$ & & \\
\hline$\odot \mathrm{S}$ & 900. & 52.000 & OSm* & & \\
\hline$\odot \mathrm{Cl}$ & $19,000$. & $1,000,000$ & $\bigcirc \mathrm{Eu}$ & & \\
\hline$\bigcirc \mathrm{A}$ & 0.6 & 28.5 & $\mathrm{Gd}$ & & \\
\hline$\odot \mathrm{K}^{*}$ & 380. & 18,000 & $\mathrm{~Tb}-$ & & \\
\hline$\odot \mathrm{Ca}$ & 400. & 19,000 & ODy & & \\
\hline $\mathrm{Sc}-$ & 0.00004 & 0.002 & Ho- & & \\
\hline$\bigcirc \mathrm{Ti}$ & 0.001 & 0.04 & $\bigcirc E_{r}$ & & \\
\hline$O \mathrm{~V}^{*}$ & 0.002 & 0.08 & $\mathrm{Tm}-$ & & \\
\hline$\bigcirc \mathrm{Cr}$ & 0.00005 & 0.002 & $\bigcirc \mathrm{Yb}$ & & \\
\hline $\mathrm{Mn}-$ & 0.002 & 0.07 & $\bigcirc \mathrm{Lu}^{*}$ & & \\
\hline$\odot \mathrm{Fe}$ & 0.01 & 0.3 & $\mathrm{OHf}$ & & \\
\hline $\mathrm{Co}-$ & 0.0005 & 0.02 & Ta* & & \\
\hline$\bigcirc \mathrm{Ni}$ & 0.0005 & 0.02 & $O W^{*}$ & 0.0001 & 0.001 \\
\hline$\bigcirc \mathrm{Cu}$ & 0.0006 & 0.02 & $\bigcirc \mathbf{R e}^{*}$ & & \\
\hline$\bigcirc Z_{n}$ & 0.001 & 0.03 & OOs & & \\
\hline$\bigcirc \mathbf{G a}$ & 0.0005 & 0.01 & OIr & & \\
\hline$\bigcirc \mathrm{Ge}$ & $<0.0001$ & $<0.003$ & $\bigcirc \mathrm{Pt}^{*}$ & & \\
\hline As- & 0.001 & 0.002 & $\mathrm{Au}-$ & 0.000004 & 0.00004 \\
\hline $\mathrm{OSe}$ & 0.004 & 0.1 & $\bigcirc \mathrm{Hg}$ & 0.00003 & 0.0003 \\
\hline$\odot \mathrm{Br}$ & 65. & 1,500 & $\mathrm{OTl}$ & $<0.00001$ & $<0.00009$ \\
\hline$\bigcirc \mathrm{Kr}$ & 0.0003 & 0.007 & $\odot \mathrm{Pb}$ & 0.003 & 0.03 \\
\hline$\bigcirc \mathbf{R b}^{*}$ & 0.12 & 3. & $\mathrm{Bi}-$ & 0.0002 & 0.002 \\
\hline$\odot \mathrm{Sr}$ & 8. & 180. & Po & & \\
\hline $\mathrm{Y}-$ & 0.0003 & 0.006 & At & & \\
\hline$\bigcirc \mathbf{Z r}$ & & & $\mathrm{Ru}$ & $9.0 \times 10^{-15}$ & $8.0 \times 10^{-14}$ \\
\hline $\mathrm{Nb}-$ & & & $\mathrm{Fr}$ & & \\
\hline OMo & 0.01 & 0.02 & $\mathrm{Ra}$ & $3.0 \times 10^{-11}$ & $2.0 \times 10^{-10}$ \\
\hline $\mathrm{Tc}$ & & & Ac & & \\
\hline$\bigcirc \mathrm{Ru}$ & & & $\mathrm{Th}^{*}$ & 0.0007 & 0.006 \\
\hline $\mathrm{Rh}-$ & & & $\mathrm{Pa}$ & & \\
\hline$\bigcirc P d$ & & & OU* & 0.002 & 0.02 \\
\hline
\end{tabular}


*印は天然放射性同位体のある元素，一印は天然には 単同位体元素と分類した。印は，今迄に報告された 元素を示す。ここでは, 試料の採集地点や樑度などが 明示されていないものとか，化学操作の省略されたも のや分折法の記載のないものなどの缺点があるものも， 一応海水について報告されたものは含めてある。また， 個々の元素についてはそれぞれの項でのべるが，特に $\mathrm{D}, \mathrm{C}, \mathrm{O}$ および $\mathrm{S}$ は多くの報告があり，それらを総 合したあのにつき考察することにする。その他の元素 は 1 例か 2 例の辫告があるにすぎないが，より多くの 元素の安定同位体比表をつくるととに主眼があるので， これらの例をやや精しく検討した。

海水の化学組成は, 岩石圈加らの風化現象による成 分の添加と, 推積その他による成分の除去などの総合 された結果のもの之考えられる。従って, 地球化学的 には一つの閉じた系として取报える。元素の量的な取 扱いにおいて晊に Goldschmidt が考えたてとがら は3，同じように同位体比を用いても考察できる。ま た，同位体比を用いる時には，海への供給途上におけ る同位体効果とか推箖途上における同位体効果などの 眞味ある現象む追跡できる。このために，各元素の地 殸 (地表) の值屯同時に記載し, 海水と地款の比較検 討を便にした。地殼の値が報告されていない元素など では，標準または参考試料あるいは同じ報文中に報告 されている鉱物などを併記し, 後日の測定結果を照合 するのに签易になる様にした。

あち万ん，全般的に考えられている如く，地表にお いては軽い質量の元素は同位体効果学受け易く，重い
元素は期待できないといわれている。現在までに重い 元素の場合の報告のある例では, $\mathrm{Ge}$ の地表における 同位体効果が認められたとするものがある4!。

同位体組成の変動を古たらす現承は，一般に元素ま たは化合物などが物理化学的変化を行うときに，その 元素の同位体が質量の違いにもとづいて示す物性の差 として，その同位体組成の変動がおきることである。 その因子としては，主に同位体交換反応，拡散，蒸発， 非可逆反応によるすのなどが考えられている。天然の 現象に扔いてはてれらのことが混合して行われるので， 必ずしも同位体効果の原因を適確に定め得ない事が多 い。

同位体比の表示の方法としては，同一元素の組成の 各員の存在量が比較的に多い場合は，各員の割合の百 分率とか比とかの形で表わすのが普通である。また特 別に一定の標準を定めておいてとれとの偏差を表わす 方法などがとられる。個々の元素については，それぞ れの項で附記する。

\section{$2 \cdot 1 \quad$ H(D) について}

都告の数は多くそれらを総合すると Fig. 1 の如く なる5)。乙の図は Rankama その他によって集められ たものであるが，他の報告においても一般的に海水の $\delta$ の值は岩石圈の值に比して負の位置を示す。測定 精度が高いので海水の值での变化範囲を利用し, 海水 の循環や気圈との比較検討および生物の関与する反応 などによく利用されている。海水中の溶存状態の研究 では水の鬥以外にも, $\mathrm{HCO}_{3}{ }^{-}$などが存在するがてれ らの量は前者の量に比べて極めて少量のため海水の代

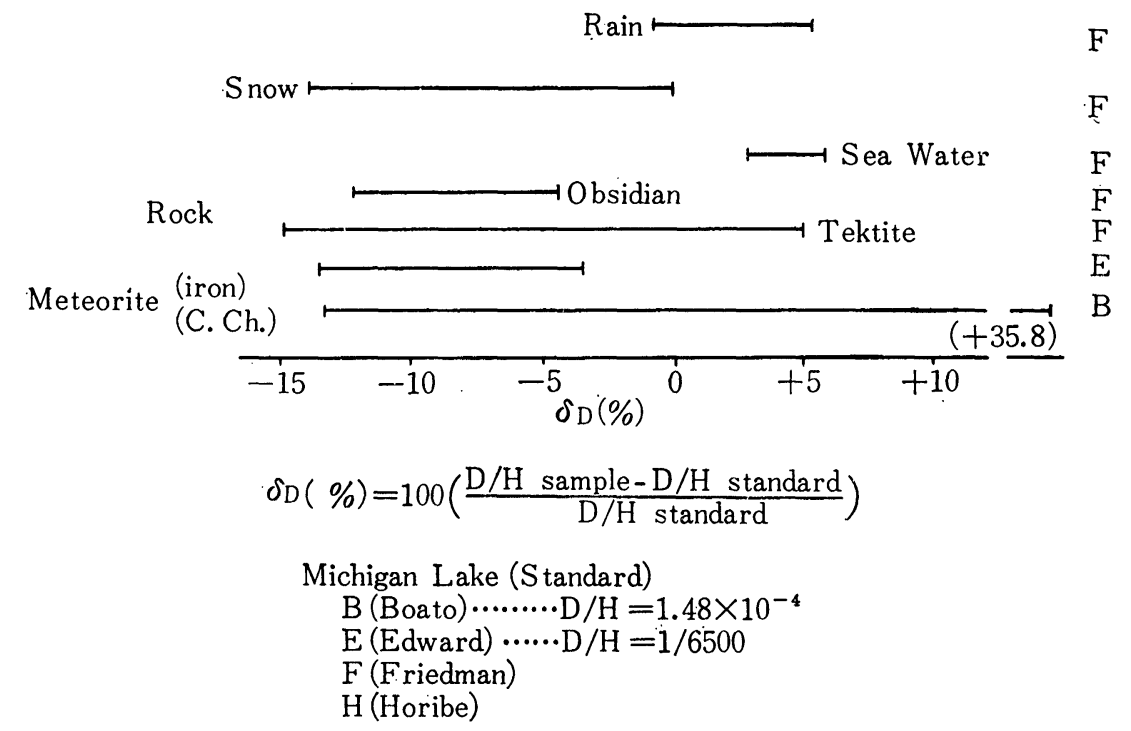

Fig. 1. Difference between D-content of hydrogen from various sources and that of an arbitary standard. 
表值には影響が少いと考えられる。通常の標準試料は， Fig. 1 に示す如くミシガン湖水を利用したものが地 球化学的研究にはよく用いられている。すちろん， SMOW 標集なども， N.B.S. の標準試料との比較に 用いられている。各研究室間の測定結果を利用する場 合に相互の連絡むよいので, 総合的な地球化学の研究 に便利な元䋕である。

\section{2・2 Li について}

質量数 6 と 7 の同位体がある。海水中の存在量は約 $2 \mu \mathrm{g} / 1$ といわれ，比較的微量の元素である。岩石圈に おいても微昷成分であり，風化現象によって海へ供給 される量もまた推䅡などによって海から除かれる量も 少いと考えられる。Shimaらによって得られた結果を

Table 2. $\mathrm{Li}$ isootpe ratio.

Mass No. 67

\section{$7.52 \quad 92.48$}

by Bainbridge et al (1950)

\section{$7 / 6$}

Sea water 12.52 surface water, Pacific Ocean

Granite $\quad 12.42$ G-1, Standard rock

Gabbro $\quad 12.58$ w-1, Standard rock by Shima et all (1964)
Table 2 に示す6)。岩石图の值と海水の值の間には大 きな変動はないと考えられるが, 推稓に伴なう或程度 の同位体効果が見られる。質量の柽い元素であるので， 地球化学的サイクルに伴ない同位体効果が期待できる 元素である。测定法の精度の上昇と測定数の增加に伴 い嬹味ある結果が得ら机る元素と考えられる。

\section{2・3 B について}

海水中の B 含有量については Goldschmidt の指 摘するごとく，海水中に異常に洲集している元絜であ る31。B の同位体比を海水について Parwell ${ }^{71}$ らが報 告したがこれには测定値がない。Shimaによって示 された結果を総合して Fig. 2 に示す8)。罒中の各圈 の数字はそこに存在する B の平均含有量を $\mathrm{g} /$ ton で 示し，横軸は $\mathrm{B}^{11} / \mathrm{B}^{10}$ を示す。岩石圈（主に火成饪石） 加ら海に供給される際に同位体効果が期待できる元素 であるが，図からは見出せない。てれは，海水生成の 初期に B が直接多量に供給されたとする説引を利用 すると，その時期に供給された B の同位体比は火成 菬と略同じで，その後の風化現像によって供給される B の同位体比に変動があっても供給显が少いために 稀釈されて現在では見出せないむのと半えられる。し かし海沓から推棈する際には多少の $\mathbf{B}^{11}$ の洲縮がある 傾问が見える。海水の蒸発残渣中の B の鉣物などで



Fig. 2. Geochiemical cycle of boron isotope. 
は同位体効果は認められる。海水值接供給する河川

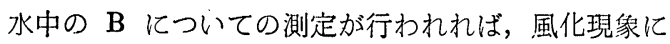
伴う同位体比の変動と海水中の值とが比較検討できる。 海水中の B の存在状態特に生物または有機物中に含 有されるむのについて，その含有量および同位体比の 測定を行う必要が地球化学的見地加らある。. ま.た，深 度とか地域性についての考虑す今後の問題となる。

\section{$2 \cdot 4 \mathrm{C}$ にいて}

数多くの報告があるが， Ingerson によって集めら れ図示されたものを Fig. 3 亿示す9。海水中の C の 存在状態は主に $\mathrm{HCO}_{3}{ }^{-}$の形のものが考えられてお り，てれ以外にも有機物の形その他のものが考えられ る。海水中の $\mathrm{HCO}_{3}^{-}$の形の $\mathrm{C}^{12} / \mathrm{C}^{13}$ と大気中の炭酸 ガスの $\mathrm{C}^{12} / \mathrm{C}^{13}$ とを比較すると，大気中に $\mathrm{C}^{13}$ の量が 少い。生物圈を経過した C 亿一般的に見られる傾向 は $\mathrm{C}^{13}$ の量が少くなる現像で，岩石圈传存する $\mathrm{C}$ とは傾向が翼なるととがわかる。

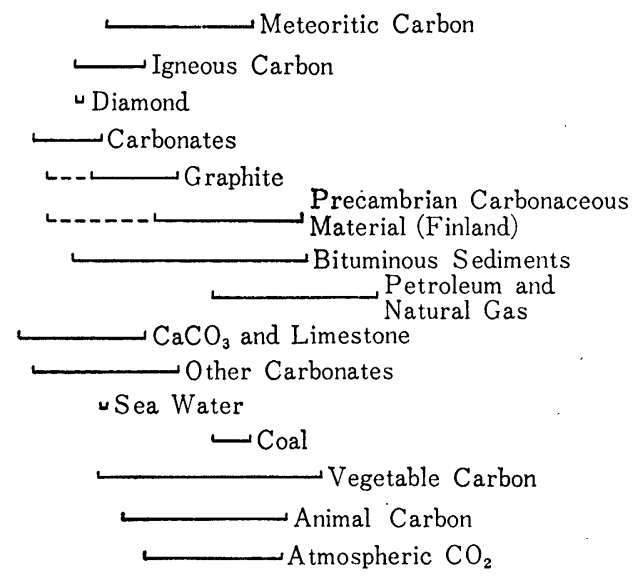

$\begin{array}{llllllllll}87 & 88 & 89 & 90 & 91 & 92 & 93 & 94 & 95 & \mathrm{C}^{12} / \mathrm{C}^{13}\end{array}$

Fig. 3. Variation of the $\mathrm{C}^{12} / \mathrm{C}^{13}$ ratio from various sources (After Ingerson).

$\mathrm{C}^{12} / \mathrm{C}^{13}$ の測定は精密に行い得るので,それを利用し て最近では植物（海棲，陸成を含む）の炭酸同化作用 による同位体変動の研究とか ${ }^{101}$ ，地殼を中心とした同 位体の地球化学的收支関係などが研究されている11)。 また水溶液中の $\mathrm{C}$ の各種の化合物の一連の無機化学 的変化化伴なう同位体効果の研究および，水溶液に共 存する $\mathrm{Mg}$ イオンの影響の研究121など，直接間接に 海水中に存在する C の同位体比の研究に関連を有す る研究が增加しつつある。

海水中の C の同位体変動は比較的飞少く，また標 準試料も全般的に広く統一されているので，地球化学 研究が行い易い。

2・5 N について

比較的に測定の例の少い元素である。Dole らは空
気中の $\mathrm{O}^{18}$ の測定に際して $\mathrm{N}^{14} / \mathrm{N}^{15}$ のととにあふれ， 4. 个所の試料について大気の值と大略同じで変動があ るに゙してあ $0.02 \%$ 以内であると報告している。彼等 は深度 $2500 \mathrm{~m}$ までの測定を行い深度による差はない 之報告した ${ }^{13)}$ 。海水中の $\mathrm{N}$ は硝酸塩, 互硝酸塩, ア ンモ二ア, 有機性のあのおよび溶存ガスのような形な ぞ種々の存在状態がある。それぞれの存在状態におけ る同位体比の測定が，最あのぞましいが，現在では僅 加 Benson らによって, aerobic な形の $\mathrm{N} に つ$ いての結果があるだけである ${ }^{14)}$ 。大気中の $\mathrm{N}^{14} / \mathrm{N}^{15}$ に 比して海の aerobic な $\mathrm{N}^{14} / \mathrm{N}^{15}$ は僅かに異なってい ると報告している。

Table 3 には，N.B.S. の㯲準試料について Junk ら が測定した值も示す。海水中に溶存するガス量む多く 測定精度す高い元素であり, また種々の形で存在し得 るので, 地球化学的にも興味の多い元素であるから今 後の発展が期待できる。

Table 3. $\mathrm{N}$ isotope ratio.

$$
\begin{array}{llc}
\text { mass No. } & 14 & 15 \\
& 99.634 & 0.366
\end{array}
$$

by Junk et al (1959)

(N.B.S. 15)

\begin{tabular}{ll}
\hline Ser water & by Dole et al (1954) \\
air & by Benson et al (1961) \\
" & by Parwell (1957)
\end{tabular}

\subsection{0 について}

安定同位体地球化学の研究において, 最も広い螌囲 に研究が行われて但り，また古くから利用されてきた 元素である。数多くの報告があるが，それらを総合す ると Fig. 4 亿なる。総合する時に共通の標準(参考) 試料のあるあのはよいが，それが見出せないものああ ろ。後者の場合は図加除去した。また同位体比の表 示法をここでは $\mathrm{O}^{16} / \mathrm{O}^{18}$ の值で示したが，多くの場 合 $\delta \mathrm{O}^{18}(\%)=\left\{\left(0^{18} / 0^{16}\right)\right.$ 試料 $/\left(0^{18} / \mathrm{O}^{16}\right)$ 標準 -1$\}$ $\times 1000$ の式で表示されている。N.B.S. で用意さ机た 標準試料は，多くの場合直接的には用いられず，八ワ イ近海の海水を利用する傾向がある。海水の值はある 筑囲の变動が見られるが，岩石圈の值に比べて $\mathrm{O}^{16} の$ 增加が考えられる。また大気と比較しても同じような 傾问がある。陸水之の比較に扝いては変動の笓囲がや や大きい。乙の変動は海水の塭分濃度と相関関係があ るとされている15)。分析精度の高いととから精密な測 定がなされ，海水の移動の研究なども行われている。 $\mathrm{O}$ の同位体の炭酸塩一水の間の分配を利用して，古

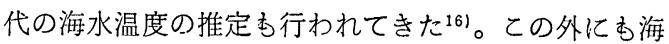
水を利用して古代気候の变遷の研究などにす利用され 


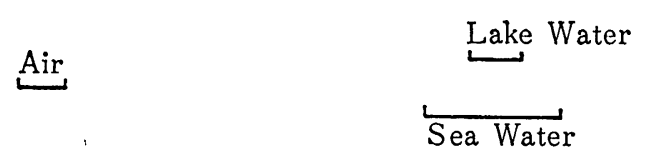

Sedimentary Rock

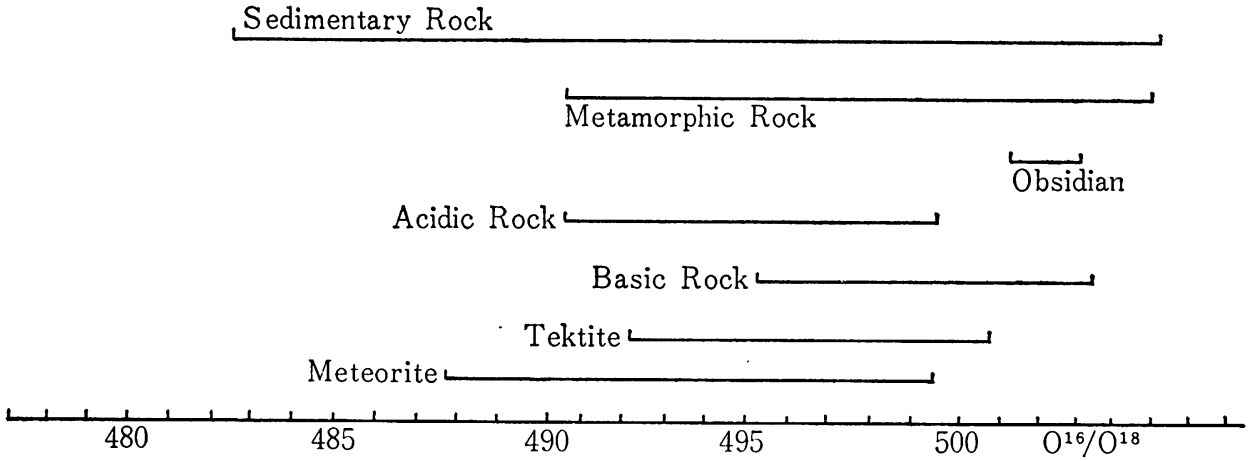

Fig. 4. Variation of the $\mathrm{O}^{16} / \mathrm{O}^{18}$ ratio from various sources (After Epstein, Emiliami and et al.).

ている ${ }^{17)}$ 。Fig. 4 に示した岩石圈の埸合，海水と同 じように，含酸素鉱物を利用しての生成温度の推定な どが行われてるが，試料が主に珪酸盐鉱物であるため にその化学処理法に問題が残っている。また海水中の $\mathrm{O}$ についても, $\mathrm{H}_{2} \mathrm{O}$ の形以外に, 溶在 $\mathrm{O}_{2}$ ガス, $\mathrm{HCO}_{3}$ - など多くの他の形の存在状態む考えられそれ ら相互間における同位体比の変遷なども與味ある問題
となろう。

\section{2・1 Mgについて}

海水中に比較的含有量の多い元絜である。Shimaに よって得られた优を Table 4 に示す ${ }^{18)}$ 。同時に地版 の岩不圈の代表として，G-1，W-1 の㢼準岩石中の $\mathrm{Mg}$ の値も示してある。海水の值と地淑の值との間に は夷験誤差以内で差がない結果である。しかし，海水

Table 4. $\mathrm{Mg}$ isotope ratio.

$\begin{array}{lc} & 25 / 24 \times 100 \\ \text { Sea water } & 12.762 \pm 0.03 \\ \text { W-1 } & 12.749 \pm 0.05 \\ \text { G-1 } & 12.748 \pm 0.05 \\ \text { Plainville } & 12.714 \pm 0.05\end{array}$

から推租した苦灭岩において苫死岩化作用に伴う多少 の同位体効果が見出せたと Daughtry らは報告して いる ${ }^{191}$ 。従って, 海水よりの推䅡に伴う現象を研少す ろのに健利な元素となる。

\section{2・8 Si について}

海水中の $\mathrm{Si}$ 成分についての報告は末だ行われてい ない。しかし,Tilles らが, 海に生育した生物の骨格中 の $\mathrm{Si}$ の同位体組成を報告している ${ }^{201}$ 。標準試料とし て, N.B.S. No.28 を用い $\delta= \begin{cases}\left(\mathrm{Si}^{30}\right) /\left(\mathrm{Si}^{28+29}\right) & \text { 試料 } \\ \left(\mathrm{Si}^{30}\right) /\left(\mathrm{Si}^{28+29}\right) & \text { 慓準 }\end{cases}$ -1\}×1000 の表示法で，例えば海洋性 Diatoms $\left(84^{\circ} \mathrm{F}\right.$ 水温, Gulf of Panama, 表酒流) が $\delta(\%)$ $=0.84 \pm 0.2$ とか, Spongeの值などがある。とれら海 成生物の值は，钽密には生物体中に吸収される時など に同位体効果がなかったとは證明されないので*，直 接的な值ではない。従って, Table 1 には除いてある。
$26 / 24 \times 100$

$\begin{array}{ll}13.966 \pm 0.02 & \text { Pacific Ocean,surface } \\ 13.965 \pm 0.04 & \text { Standard rock } \\ 13.984 \pm 0.03 & \text { Standard rock } \\ 13.885 \pm 0.02 & \text { Stone Meteorite }\end{array}$

by Shima (1964)

\section{2・9 S について}

海水中の存在状態については, 主に $\mathrm{SO}_{4}=$ の形が, 量的に見て重要となる。広範四の試料についてその結 果を総合すると Fig 5 になる21。 海水の值は極めて 変動筈囲の小さい事がわかる。 $\mathrm{SO}_{4}$ - 以外の形で在存 すると考えられるものについての結果はない。岩石圈 その他の圈との比較においては約 $20 \%$ ほど $\mathrm{S}^{34}$ を 濃縮していることになる。乙れと関連があるが，推积 作用（特に海底における）に伴ない海水中の $\mathrm{S}$ がバ クテリヤ（硫酸茺元）などによる同位体効果が大きい 具が洘えられている22!。

\section{2・10 Cl について}




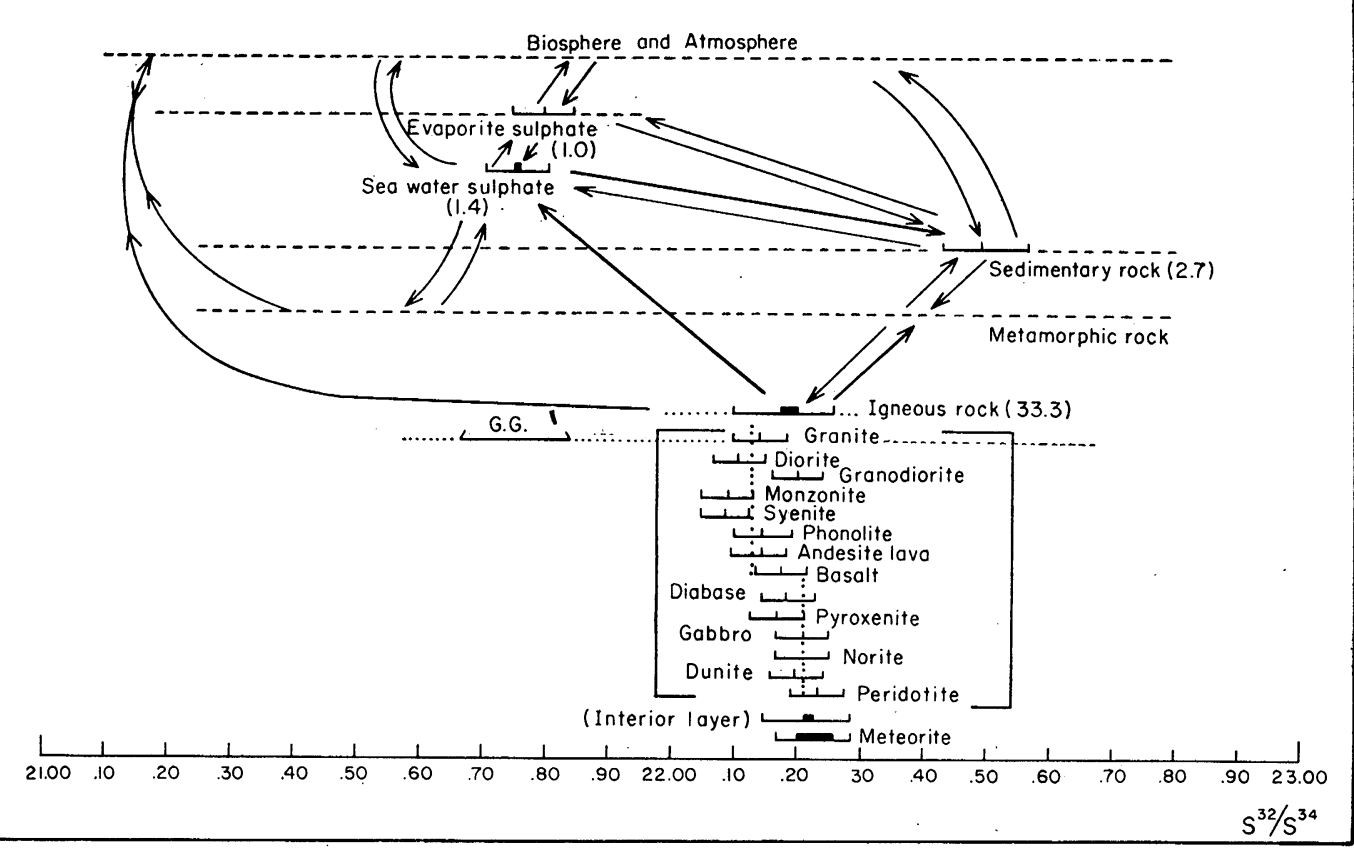

Fig. 5. Geochiemical cycle of sulfur isotope.

Table 5. $\mathrm{Cl}$ isotope ratio.

Mass No $\quad 35 \quad 37$

$\begin{array}{ll}75.770 & 24.229\end{array}$

by Shields et al (1962)

\begin{tabular}{|c|c|c|}
\hline \multicolumn{3}{|c|}{$35 / 37$} \\
\hline & Standard & Sample \\
\hline Sea water & 3.146 & Atlantic Ocean, Eastern Long Island \\
\hline Obsidian & 3.142 & Obsidian Cliff Wyoming \\
\hline Gabbro & 3.143 & Shelby, North Carolina \\
\hline Halite & 3.125 & New Gulf Salt Dome Texas \\
\hline \multicolumn{3}{|c|}{ mean value $=3.13 \pm 0.03$} \\
\hline & & by Owen et al (1955) \\
\hline \multicolumn{3}{|c|}{$\delta \mathrm{Cl}^{37}=\frac{(37 / 35) \text { sample }-(37 / 35) \text { standard }}{(37 / 35) \text { standard }} \times 1000$} \\
\hline \multicolumn{3}{|r|}{ Standard (N. B. S. no 105) } \\
\hline & $\delta \mathrm{Cl}^{37}(\%)$ & \\
\hline Sea water & $+0.07 \sim-0.2$ & Gulf of Mexico, 7 samples, depth $(\mathrm{O}-6520 \mathrm{~m})$ \\
\hline Sea water & $+0.7 \sim 0$ & Pacific Ocean, 8 samples, depth $(\mathrm{O}-3033 \mathrm{~m})$ \\
\hline Halite & 0.0 & \\
\hline Granite & $-0.1 \pm 0.5$ & Chelmsford \\
\hline Obsidian & $+0.5 \pm 0.5$ & Lake Co., Oregon \\
\hline Gabbro & $+0.5 \pm 0.5$ & Iron Mt., Colorado \\
\hline Chondrite & $-0.4 \pm 0.5$ & $\begin{array}{l}\text { Plainview, Texas } \\
\text { by Hoering et al (1961) }\end{array}$ \\
\hline & & $-31-$ \\
\hline
\end{tabular}


海水の主姴成分の一つで，眼に 1920 年代に原子量 の決定を行なう際分折が行われていた。Owen らは標 準試料として市販品の $\mathrm{NaCl}$ (海産)を用い，乙れと比 較して海水の值を得た。岩石圈との比較㭘討む行われ た ${ }^{23)}$ 。乙れらをTable 5 亿示す。また Hoering らは N.B.S. の標準試料 (No. 105) を用い $\delta \mathrm{Cl}^{37}$ を Table 5 亿示す表示で測定を行なった。大西洋の試料は大平
洋の値に比して $\delta$ 值が低い傾向がある。また深度によ っての変化はあまり見出せない。岩石图と水圈との比 較においてはあまり差はないが，隤石との比較におい ては海水の方が $\delta$ 值が高いととを報告している ${ }^{24)} 。$

\section{2・11 K について}

$\mathrm{K}$ の安定同位体は 39 と 41 である。Brewer らの 結果を Table 6 に示す。海水の深度による変動は見

Table 6. $\mathrm{K}$ isotope ratio.

\begin{tabular}{|c|c|c|c|}
\hline Mass No. & $\begin{array}{l}39 \\
93.08\end{array}$ & $\begin{array}{l}40^{*} \\
0.0119\end{array}$ & Sylvite, by Nier (1950) \\
\hline & $39 / 41$ & & \\
\hline Sea water & 14.20 & surface, off Brown Island & \\
\hline$\because$ & 14.20 & surface, Pole Pass between & n Crance Island \& Deer Harbor \\
\hline " & 14.20 & surface, Peavince Pass off & f Blakley Island \\
\hline " & 14.22 & surface, East Sound off O & Olga Island \\
\hline " & 14.20 & surface, Haro Strait Island & \\
\hline " & 14.20 & $100 \mathrm{~m}$ depth, " & \\
\hline " & 14.21 & surface, 25 miles in from & Cape Flattery \\
\hline " & 14.20 & $185 \mathrm{~m}$ depth, & " \\
\hline " & 14.20 & $\begin{array}{l}200 \mathrm{~m} \text { depth, } 120 \text { miles } \\
\left(48^{\circ} 24^{\prime} \text { N., } 128^{\circ} 01^{\prime} \mathrm{W} .\right)\end{array}$ & west of Cape Flattery \\
\hline " & 14.21 & surface, West of Cape $\mathrm{Fla}_{\mathrm{a}}$ & lattery $\left(47^{\circ} 54^{\prime} \mathrm{N}^{\prime}, 126^{\circ} 33^{\prime}\right.$ W. $)$ \\
\hline " & 14.19 & $2000 \mathrm{~m}$ depth, & " \\
\hline " & 14.20 & $\begin{array}{l}\text { surface, South and West } 0 \\
\left.47^{\prime} \mathrm{W} .\right)\end{array}$ & of Cape Flattery $\left(46^{\circ} 39^{\prime}\right.$ N., $127^{\circ}$ \\
\hline " & 14.20 & $1000 \mathrm{~m}$ depth, & " \\
\hline " & 14.20 & $2500 \mathrm{~m}$ depth, & " \\
\hline Basalt & 14.11 & Hawaii, U.S.A. & \\
\hline Granite & 14.24 & Colarado, U.S.A. & \\
\hline Shale & 14.25 & Wyoming, U.S.A. & \\
\hline
\end{tabular}

by Brewer $(1937,1939)$

$\begin{array}{ll}\text { Sea water } & 14.06 \quad \text { Gulf of Bothnia } \\ \text { Orthoclase } & 14.07 \\ \text { Leucite } & 13.96,14.17\end{array}$

by Reuterswärd (1956)

Table 7. $\mathrm{Ca}$ isotope ratio.

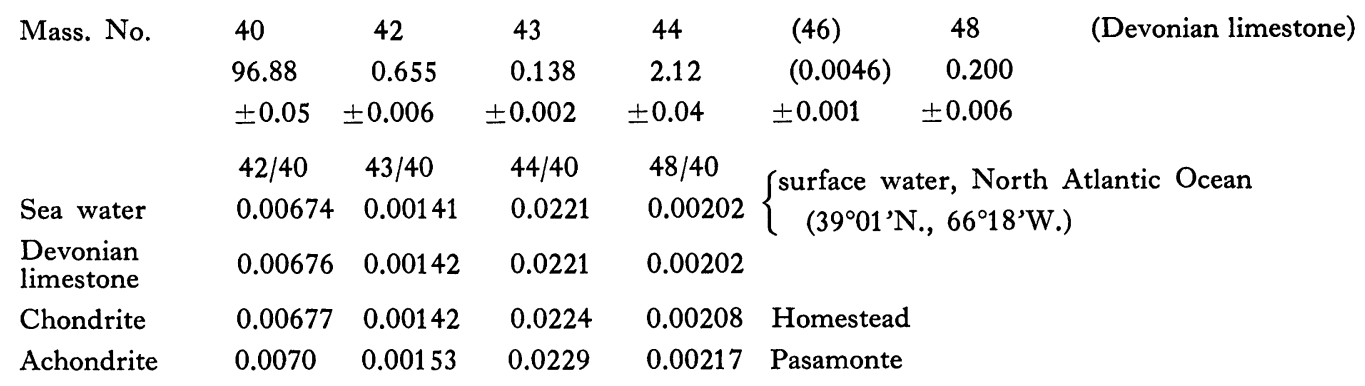

by Pinson et al $(1957,1964)$ 
出せず, 平均值として $\mathrm{K}^{39} / \mathrm{K}^{41}$ の值を 14.20 として (る ${ }^{25)}$ 。岩石圈之の比較も行わ抽, 海水之の間任変動 は見出せないと報告している。Reuterswärd む Table 6 の如き結果を報告している ${ }^{26)}$ 。両報告の間には海水 について差が認められるが，共通標準試料がないので, 数值の直接比較検討はできない。乙れらの報告では海 㜀生物中で同位体効果が期待できるとの結果が得られ た。隕石之岩石图との比較は別の標準試料によって Rik らによって行われたが，差は見出せなかった27。

\section{2・12 Ca について}

$\mathrm{Ca}$ は海水を中心に地球化学的な輪回を考えると, 強く生物の因子を加味して考えねばならない。海水の 同位体組成比を Table 7. 亿示す。てれは Pinson ら によって得られたもので, 岩石圈や隕石との比較にお いても大きな变動はない281。しかし, 生物圈にとり込
まれた場合の同位体効果は期待できるし，特に炭酸塩 鉱物の推積に伴う䟢の変動などは, $\mathrm{S}$ の同位体比によ る古代海水の組成推定を行う場合と同じように考慮し なければならないと考えられる。

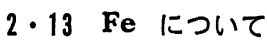

宇宙およで地球において存在度の大きい元素であり， 地表における存在状態も種々の化合物として考えられ るので，形態の変化と共に同位体組成の変動が興味あ る対象となる。海水中でも色々な状態が考えられるが， こてでは全鉄としての同位体比を考える。 Shima に よって得られた結果を Table 8 亿示す。岩石圈の值 あ全鉄の結果である。海水と岩石圈の比較において大 きな同位体効果は認めら机ない，しかし Fe の存在状 態を個々に比較検討すれば興味ある結果が期街できる であろう。

Table 8. $\mathrm{Fe}$ isotope ratio.

$\begin{array}{lccccl} & 54 & 56 & 57 & 58 & \\ \text { Sea water } & 6.30 \pm 0.06 & 100 & 2.32 \pm 0.04 & 0.32 \pm 0.01 & \text { Pacific Ocean, surface } \\ \text { W-1 } & 6.32 \pm 0.04 & 100 & 2.33 \pm 0.03 & 0.32 \pm 0.01 & \text { Standard rock } \\ \text { G-1 } & 6.35 \pm 0.08 & 100 & 2.34 \pm 0.04 & 0.32 \pm 0.02 & \text { Standard rock } \\ \text { Canyon Diablo } & 6.29 \pm 0.07 & 100 & 2.33 \pm 0.03 & \begin{array}{c}0.33 \pm 0.01 \\ \text { by Shima }\end{array} & \text { Iron-Meteorite }\end{array}$

\section{2・14 Br について}

海水中の $\mathrm{Br}$ の同位体について, Cameron らは, Table 9 亿示す結果を報告している。彼等は， $\mathrm{Na}$ $\mathrm{Br}^{79+} / \mathrm{NaBr}^{81+}$ の比として, 同位体比を求めた。同時 に $\mathrm{Br}$ の濃縮している石油被水についても求め, 海水

Table 9. $\mathrm{Br}$ isotope ratio.

Mass No. 7981

$50.68649 .314 \quad$ N. B. S. standard $79 / 81=1.02784$

by Catanzaro (1964)

\begin{tabular}{lrl}
\hline & $79 / 81$ & \\
Sea water & 1.0214 & Pacific Ocean \\
Brine & 1.0224 & Seurles Lake \\
" & 1.0231 & $\begin{array}{l}\text { Michigan } \\
\text { by Cameron et al (1955) }\end{array}$ \\
\hline
\end{tabular}

$\begin{array}{lll}\text { Sea water } & 0.9992 & \\ \text { Brine } & 0.9988 & \\ \text { " } & 0.9999 & \\ \text { Carnallite } & 0.9992 & \text { Stassfurt, Germany } \\ \text { Bromyrite } & 0.9990 & \text { Broken Hill, Australia } \\ \text { Sylnite } & 0.9988 & \text { Nebra, Germany }\end{array}$

* (79/81) sample/(79/81) reference

by Catanzaro et al (1964)

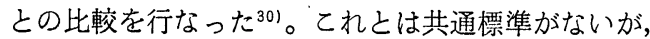
Catanzaro らが, N.B.S. の標準を基として， Table 9 亿示す結果を得た ${ }^{311}$ 。表示の方法は表の中に示して ある。Catanzaro の結果では, 海水と䶢水との間およ び含 $\mathrm{Br}$ 鉱物との間には大きな同位体変動は認められ ない。

\section{2・15 Sr について}

$\mathrm{Sr}$ の同位体は年代決定法に利用されるので，測定 の精度が上昇しつつある。古くは Herzog らが海水の 值之, 鉱物の值を比較し, $\mathrm{Sr}^{86} / \mathrm{Sr}^{88}$ について变動は ないと報告した ${ }^{321}$ 。その後 Ewald らが， $\mathrm{Sr}^{86} / \mathrm{Sr}^{88}$ ， $\mathrm{Sr}^{87} / \mathrm{Sr}^{88}$ を海水之食 $\mathrm{Sr}$ 鉱物について測定し Table 10 亿示す結果を得た ${ }^{331}$ 。海水だけで他の圈との比較 は出来ないが, Pinson らは Table 10 の結果を示し ている34)。最近, Faure らによって精しく総合報告さ れた。Table 11 に北太西洋での結果を示す。ての表 の標準試料を基準として Ewald, Pinson, Gast, Compston らが個々に得た結果を $\mathrm{Sr}^{86} / \mathrm{Sr}^{88}$ の值で比較 换算を行ない，多くの報告を縓める試みをしている。 また Faure らが自身の測定結果で岩石圈との同位体 変動を比較検討し, 風化現象に伴う同位体効果を論じ ている35)。

\section{2・16 Pb について}

海水中の $\mathrm{Pb}$ 同位体組成の報告は意外飞少い。 Table 12 に Patterson によって報告されたものを示 
Table 10. Sr isotope ratio.

\begin{tabular}{|c|c|c|c|c|c|}
\hline Mass No. & $\begin{array}{l}84 \\
0.58\end{array}$ & $\begin{array}{l}86 \\
9.99\end{array}$ & $\begin{array}{l}87 \\
7.14\end{array}$ & $\begin{array}{l}88 \\
82.29\end{array}$ & $\begin{array}{l}\text { Synthetic } \\
\text { aluminosilicate } \\
\text { by Akishin et al (1956) }\end{array}$ \\
\hline & $84 / 88$ & $86 / 88$ & $87 / 88$ & $87 / 86$ & \\
\hline Sea water & & 0.1195 & & 0.718 & \\
\hline Strontianite & . & 0.1194 & & 0.710 & $\begin{array}{l}\text { Ascheberg Okerkreide } \\
\text { by Ewald et al (1956) }\end{array}$ \\
\hline Sea water & 0.0067 & 0.1189 & 0.0845 & 0.712 & $\begin{array}{l}\text { North Atlantic Ocean }\left(39^{\circ} 01^{\prime}\right. \\
\left.\text { N., } 66^{\circ} 18^{\prime} \text { W. }\right)\end{array}$ \\
\hline
\end{tabular}

Table 11. Measurements of the isotopic composition of strontium in surface water from the North Atlantic Ocean.

\begin{tabular}{|c|c|c|c|c|}
\hline No. & $\mathrm{Sr}^{86} / \mathrm{Sr}^{88}$ & $\mathrm{Sr}^{87} / \mathrm{Sr}^{86}$ & $\left(\mathrm{Sr}^{87} / \mathrm{Sr}^{86}\right)_{\text {corr }}$ & Remarks \\
\hline $\begin{array}{l}\text { 1. Northumberland Staraites } \\
\text { Nova Scotia }\end{array}$ & 0.1190 & 0.7104 & 0.7092 & \\
\hline 2. North Atlantic & 0.1189 & 0.7114 & 0.7099 & \\
\hline $39^{\circ} 01^{\prime} \mathrm{N}, 66^{\circ} 18^{\prime} \mathrm{W}$ & 0.1188 & 0.7112 & 0.7094 & \\
\hline $\begin{array}{l}\text { 3. Off Delaware Bay, inside } \\
\text { Gulf Stream, } 38^{\circ} 36.5^{\prime} \mathrm{N} \\
72^{\circ} 09^{\prime} \mathrm{W}\end{array}$ & 0.1187 & 0.7112 & 0.7092 & \\
\hline $\begin{array}{l}\text { 4. Off Cape Lookout } \\
34^{\circ} 02^{\prime} \mathrm{N}, 75^{\circ} 41^{\prime} \mathrm{W}\end{array}$ & 0.1189 & 0.7107 & 0.7092 & \\
\hline 5. East of Savannah, $\mathrm{Ga}$, in Gulf & 0.1186 & 0.7124 & 0.7100 & \\
\hline Stream, $31^{\circ} 52^{\prime} \mathrm{N}, 77^{\circ} 18^{\prime} \mathrm{W}$ & 0.1186 & 0.7113 & 0.7089 & \\
\hline $\begin{array}{l}\text { 6. } 10 \text { miles } \mathrm{NW} \text { of Bimini, Bahamas, } \\
\text { approx: } 26^{\circ} 0^{\prime} \mathrm{N}, 79^{\circ} 20^{\prime} \mathrm{W}\end{array}$ & 0.1189 & 0.7112 & 0.7097 & \\
\hline $\begin{array}{l}\text { 7. } 35 \text { miles } \mathrm{E} \text { of Eleuthera, Bahamas, } \\
\text { approx. } 25^{\circ} 0^{\prime} \mathrm{N}, 75^{\circ} 40^{\prime} \mathrm{W}\end{array}$ & 0.1195 & 0.7087 & 0.7090 & \\
\hline 8. Bermuda, $32^{\circ} 10^{\prime} \mathrm{N}, 6727^{\prime} \mathrm{W}$ & 0.1193 & 0.7100 & 0.7097 & \\
\hline 9. Near Equator $02^{\circ} 40^{\prime} \mathrm{N} 20^{\circ} 55^{\prime} \mathrm{W}$ & 0.1198 & 0.7081 & 0.7092 & \\
\hline $\begin{array}{l}\text { 10. Off coast of Liberia, W. Africa, } \\
07^{\circ} 51^{\prime} \mathrm{N}, 13^{\circ} 22^{\prime} \mathrm{W}\end{array}$ & 0.1183 & 0.7119 & 0.7086 & \\
\hline $\mathrm{SrCO}_{3}$, Eimer \& Amend lot 492327 & 0.1193 & 0.7088 & $\begin{array}{l}0.7084 \\
\pm 0.0003(\sigma)\end{array}$ & $\begin{array}{l}\text { Nine analyses } \\
\text { from } \\
\text { December } \\
1962 \text { to } \\
\text { August } 1963\end{array}$ \\
\hline
\end{tabular}

by G. Fude, P. M. Hureey and J.L. Powell (1965)

す。海水の採水地点は明らかでない36)。乙れ以外には， Patterson ら ${ }^{371}$ および Chow ら ${ }^{381}$ により Mn-Nodule 中の $\mathrm{Pb}$ 同位体組成の報告があるが，乙机は㨁接海水 中の $\mathrm{Pb}$ を測定したあのでない。Table 12 から, 岩 石圈や隕石との間の比較検鲴ができる。この場合, Patterson らによって報告されたものだけであるから


定において N.B.S. の愫準試料(例えば No. 200b) に ついて多くの研㘳室で得た結果は一致していない399。 年代決定法などによく利用さ机る䒕素なので問題であ ろう。最近，海水中に供給される $\mathrm{Pb}$ が天然現象によ
るものだけでなく，人工的な供給（例えばガソリン添 加物の行動など）も考えられるので, 困難な因子が增 える傾向である。

\section{$2 \cdot 17$ 天然放射性同位体について}

安定同位体之深い関連のある天然放射性同位体につ いても，特に海水について興味ある報告が多い。天然 放射性同位体は一般に测定法が安定同位体に比して比 較的に容易であるので，海水研劣に際しても数多くの 試みがなされる。Table 1 の*印の元素について顺次 跟告する。 $T$ は守宋線による核反応 (主飞 $\mathrm{N}^{14}(n, t)$ $\mathrm{C}^{12}$ ) で，大気中で生成し， $\mathrm{H}$ などと共に海水に供給 
Table 12. $\mathrm{Pb}$ isotope ratio.

\begin{tabular}{|c|c|c|c|c|c|}
\hline Mass No. & $\begin{array}{l}204 \\
1.53\end{array}$ & $\begin{array}{l}206 \\
22.63\end{array}$ & $\begin{array}{l}207 \\
22.68\end{array}$ & $\begin{array}{c}208 \\
53.13 \\
\text { by Dibele }\end{array}$ & $\begin{array}{l}\text { (N.B.S. No. 200b) } \\
(1960)\end{array}$ \\
\hline & 204 & 206 & 207 & 208 & \\
\hline Sea water & 1.00 & 19.04 & 15.69 & 39.00 & Pacific Ocean \\
\hline Basalt & 1.00 & 18.12 & 15.45 & 38.08 & Idaho, \\
\hline Granite & 1.00 & 19.15 & 15.20 & 37.37 & Ontario, Canada \\
\hline Meteorite & 1.00 & 9.50 & 10.36 & 29.16 & Canyon Diablo \\
\hline " & 1.00 & 19.48 & 15.76 & $\begin{array}{l}38.21 \\
\text { by } \mathrm{P}\end{array}$ & $\begin{array}{l}\text { Chondrite, Modoc } \\
\text { erson }(1953,1956)\end{array}$ \\
\hline
\end{tabular}

される。半減期約12年で, 比較的短い期間での海水の 移動および混合の追跡などに重要な研究の手懸りを与 えている ${ }^{40)} 。 B e^{7}$ および $B e^{10}$ も，宇宙線によって生 成され，海水中に供給される ${ }^{411}$ 。前者はその半減期約 53.5 日を利用し, ごく短い水圈の追跡子として用いら れ, 後者は, $2.5 \times 10^{6}$ 年の長い半減期を利用して海底

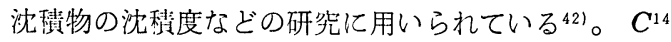
あ宇宙線生成元素 $\left(\mathrm{N}^{14}(n, p) \mathrm{C}^{14}\right)$ で半減期約 5600 年の 元素である。 $C^{14}$ は大気中の他の $\mathrm{C}^{12}, \mathrm{C}^{13}$ 之同様に行 動すると考えられ，大気中加海水化供給され海水中 に存在する。あち万ん，(気圈)心(水圈)の間における $\mathrm{C}^{12}, \mathrm{C}^{13}$ および $\mathrm{C}^{14}$ の同位体効果などは，充分検討 されている ${ }^{43)}$ 。海水中の存在する $\mathrm{C}^{14}$ を追跡子とす る比較的長期の海水の移動, 混合の研究が行われてい $3^{44)}$ 。 $K^{40}$ については, 大平洋の海草の一種に $\mathrm{K}^{39} /$ $\mathrm{K}^{41}$ の比で，大きな同位体効果のあるあのがあり ${ }^{26)}$ ， これとの関連において同じような傾向が $\mathrm{K}^{39} / \mathrm{K}^{40}$ お よび $\mathrm{K}^{41} / \mathrm{K}^{40}$ について考えられる。 $R b^{87}$ は $\mathrm{K}^{40}$ よ 同様に年代決定法に利用されている。水圈の值は Brewer らの温泉水のあのが古くある。Compston に よってオーストラリヤ近海の海水試料 4 種についての 測定報告がある ${ }^{45)}$ 。 $T h^{232}$ 亿ついては，同位体の Io および塤変に伴う種々の同位体例えば $\mathrm{Ra}$ などが海水 および海底推積物中で行㲜する際の化学的変化とそれ ぞれの放射平衝との関連から, 深成推樍物の年代測定 などに利用されている46)。U も年代決定法に重要な 元素であるが, 海水之海底沈積物との間で, そ扎ぞ机 の U の同位体の壊変元素を用いて, Th 之同漛に沈 積度の研究などが行われている ${ }^{47)}$ 。U は Th と共に 雨方の元素の壊変生成物を適当に組合せて上記のよう な研究も多く行われている。また，U の同位休につ いては，風化現象に伴う同位休变動の報告がある このととは, 岩石圈から海水へ供給されるU の同位 体組成の変動についての模型实験もあり ${ }^{49)}$ ，今後の興 味ある問題である。

これ以外にあ， $V^{50}, L u^{176}$ その他の天然放射性同位
体および人工放射性同位体などの研究を報告すべきだ が，ここでは省略する。

\section{3. むす び}

以上, 海水中に存在する化学元素のうち同位体比の 報告のあるあのについてのべた。ててい外の元素につ いて，稀ガスは測定の進歩と共に当然報告があるべき であるが，僅か汇 Goldberg らによって，稀ガス間 の溶在量の比についての報告があるだけである ${ }^{50) 。 ま ~}$ た, 含有量が極く徽量で化学成分表にも記載されてい ない稀土類元素の如きすのむ当然それらの同位体組成 は不明である。Table 1 をみると, $\mathrm{Ti}, \mathrm{Cr}, \mathrm{Zr}, \mathrm{Ba}$ などは現在の测定技術をもってすれば分析可能な元素 である。

上述してきた同位体比の表は, 海水を中心にして主 にその安定同位体比について䌦めた。てれ以外にも元 蒵によっては，報告のあったものもあるが，岩石圈， 気圈などと直接比較検討できない報告は除いてある。 また 1 例だけの報告しか見出せない元素であってあ， 海水の代表として使用した。数多くの報告のある元素 については，篚者が代表们と考えるすのだけを引用し て文献に示した。

ここに示された值は, 将来測定法の改良, 試料数の 增加などで，変化するであろうし，また筆者の努力の 不足加ら多くの見落した文献も多い之考えている。し かし，乙てに集めた結果加(岩石圈) $\rightarrow$ (水圈)への移 行に伴う同位体变動よりも，(水圈) $\rightarrow$ (推槛圈)への移 行に伴う変動が大きい傾向が見出せる。との上に（生 物圈) の因子が加わると, 益々興味ある研究が行い得 る。

化学元素の念有量を尺度とした海水の化学成分の表 が, 古く加, 改定を重ねつつお, 海の地球化学的研 究に，常に一つの指針を与えて来た様に，現在の同位 体比の集棓を利用して, 海水の同位体地球化学の発展 に，何らかの貢獻を与える余地があるとすれば，望外 の喜びである。 


\section{交 \\ 質 量 分 析}

\section{文献}

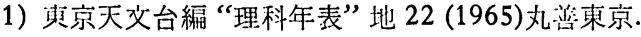

2）品誠，質量分析，24号，173 (1964).

3) V.M.Goldschmidt, J.Chem. Soc., 655 (1937).

4) R.P.Graham, J.Macnamara, I.H.Crocker and R.B.MacFarlane, Can. J. Chem., 29, 89 (1951)

5) G.Boato and H.Craig, Atti 1 Convegno Geol. Nucleare, Roma, 22 (1955); G.Edwards, Nature, 176, 109 (1955); 1. Friedman, Proc. 2nd Conf. cn Nuclear Processes in Geologic Setting 1 (1956);

6) Makoto Shima and M.Honda, J. Geophys. Res., 65, 2849 (1963).

7) A.Parwell, H. von Ubish and F.E.Wickman, Geochim. et Cosmochim. Acta, 10, 185 (1956).

8）皂誠, 質量分析, 25号, 7 (1964).

9) E.Ingerson, Bull. Geol. Soc. Am., 64, 301 (1953).

10) P.Park and S.Epstein, Plant Physiolc.gy, 36, 133 (1961).

11) H.Craig, Geochim. et Cosmochim. Acta, 3, 53 (1953).

12) H.G.Thode, M.Shima, C.E.Rees and K.V. Krishnamurty, Can. J. Chem., 43, 582 (1965).

13) M. Dole, G. A. Lang, D.P. Rudd and D.A. Zaukelies, Geochim. et Cosmochim. Acta, 6, 65 (1964).

14) B.B.Benson and P.D.M.Parker, Deep-Sea Research, 7, 237 (1961).

15) S.Epstein and T.Mayeda, Geochim. et Cosmochim. Acta, 4, 213 (1953).

16) S.Epstein, R.Buchsbaum, H.Lowenstam and H.C.Urey, Bull. Geol. Soc. Am., 62, 417 (1951).

17) C.Emiliani, J. Geol., 63, 538 (1955)

18) Makoto Shima, Bull. Chem. Soc. Japan, 37, 284 (1964).

19) A.C.Daughtry, D.Perry and M.Williams, Geochim. et Cosmochim. Acta, 26, 857 (1962).

20) D.Tilles, J. Geophys. Res., 66, 3003 (1961).

21) 8) に同じ

22) H.G.Thode, J.Monster and H.B.Dunford, Geochim. et Cosmochim. Acta, 25, 159 (1961).

23) H.R.Owen and O.A.Schaeffer, J. Am. Chem. Soc., 77, 898 (1955).

24) H.G.Hoering and P.L.Parker, Geochim. et Cosmochim. Acta, 23, 186 (1961).

25) A.K.Brewer, J. Am Chem. Soc., 58, 370 (1936).

26) C.Reuterswärd, Arkiv Fysik, 11, 1 (1956).

27) G.K.Rik and Yu.A.Shukolyukov, Doklady Akad. Nauk S.S.S.R., 94, 667 (1954).

28) W.H.Pinson, L.F.Herzog, P.A.Anderson and
R.F.Cormier, Bull. Geol. Soc. Am., 68, 1781 (1957); M.M.Backus, W.H.Pinson, L.F.Herzog and P.M.Murley, Geochim. et Cosmachim. Acta , 25, 735 (1964).

29）鼠誠，岩石鉱物鉱床学会誌，53, 228 (1965).

30) A.E.Cameron and E.L.Lippert, Science, 121, 136 (1955).

31) E.J.Catanzaro, T.J.Murphy, E.L.Garner and W.R.Shields, J. Research, N.B.S., 65A, 593 (1964).

32) L.F.Herzog, L.T.Aldrich, W.K.Holyk, F.B. Whiting and L.H.Ahrens, Trans, Am. Geophys, Union, 34, 461 (1953).

33) H.Ewald, S.Garbe and P.Ney, Z. Naturforsch, 11a, 521 (1956).

34) 28) に同じ

35) G.Faure, P.M.Hurley and J.L.Powell, Geochim. et Cosmochim. Acta, 29, 209 (1965).

36) K.Rankama "Progress in Isotope Geology" pp 469 (1963), Interscience, N.Y.

37) C.C.Patterson, E.D.Goldberg and M.G.Ingram, Bull. Geol. Soc. Am., 64, 1387 (1953).

38) T.J.Chow and C.C.Patterson, Bull. Geol. Soc. Am., 68, 1708 (1957).

39) F.L.Mohler, Technical Note, 51, (1960) N.B.S.

40) F.Begemann and W.F.Libby, Geochim. et Cosmochim. Acta, 12, 277 (1957).

41) J.R.Arnold and H.Ale. Al-Salih, Science, 121, 451 (1955).

42) J.R.Merrill, E.F.X.Lyden, M.Honda and J.R. Arnold, Geochim. et Cosmochim. Acta, 18, 108 (1960).

43) H.Craig, J. Geol., 62, 115 (1954).

44) H.Craig, "Earth Science and Meteoritics" pp 103 (1963), N.Holland Pub., Amsterdam.

45) W.Compston and R.T.Pidgeon, J. Geophys. Res., 67, 3493 (1962).

46) E.Piccotto and S.Wilgain, Nature, 173, 632 (1954).

47) J.N.Rosholt, Bull. Geol. Soc. Am. 68, 1788 (1957).

48) J.N.Rosholt, E.L.Garner and W.R.Shields, U.S. Geol. Survey, Prof. Paper, 501-B, B 84 (1964).

49) I.P.Koshelev and N.G.Syromyatnikov, Fzvest. Akad. Nauk Kazahl, SSR, Ser Geol. no. 3, 73 (1961).

50) R.Bieri, M.Koide and E.D.Goldberg, Science, 146, 1035 (1964). 